\title{
Mealtime and meal patterns from a cultural perspective
}

\author{
Christina Fjellström
}

Department of Domestic Sciences, Uppsala University, Uppsala, Sweden

Abstract

The meal is universal, existing in every society, culture and social class, but its symbolic meanings differ across individuals and groups. Encyclopaedias define a meal as a certain amount of food eaten at a specific time, some researchers define the meal as part of the eating space, and some by nutritionally distinguishing meals from eating events, such as snacks. Meal patterns and meal orders in Sweden have changed considerably over the centuries according to historical evidence. In modern society there is a tendency towards increased grazing behaviour and perhaps also towards a decrease in sharing family meals, but these phenomena require further investigation. Research on meals, or "meal research", has been developed and now represents two new academic disciplines in Sweden. The first department to establish this new academic discipline by establishing a professorship was the Department of Domestic Sciences, Uppsala University. The aim of meal research is to take a holistic perspective on nutrition and food studies, to which studies at the department have contributed during the past decade.

Keywords: culture; meal patterns; meal research; mealtime

\section{Introduction}

Research on food, meals and nutrient intake has been on the agenda for more than century; however, the number of scientific studies has increased significantly since the middle of the twentieth century (1-4). In this development, social and cultural aspects of people's food habits, involving people's attitudes and the motives behind their food choice, have been recognized as important factors when, for example, studying food habits from a health perspective. By placing emphasis on time, space and social aspects, different dimensions of the meal can be observed. These dimensions include the meal situation, meal order, meal patterns and meal situations, i.e. practices and rituals at the table. The meal is universal, existing in every society, culture and social class, but its symbolic meanings differ across individuals and groups (5-7). Although the three-meal-a-day pattern and words signifying three distinct meals are widespread around the world, meals such as breakfast, lunch and dinner have different structures, and people thus consciously or unconsciously give these meals different cultural meanings. For some, lunch or breakfast is more important and considered a proper meal, while others give dinner this cultural meaning $(6,8)$. This is true also when studying meals and eating events in Scandinavia (9). The meal structure, the daily rhythm of eating, the social context of eating and the meal format, including what is considered or not considered a proper meal, differ among the Nordic countries. Thus, when people choose how to combine foods into meals and other eating events, they show how these can have different important meanings depending on the situation, at what stage they are in the life cycle, their gender, socioeconomic status, ethnicity and many other factors $(10-13)$.

\section{Meal definitions}

For most of us, a meal is something that we feel we understand. Encyclopaedias define a meal as a certain amount of food eaten at a specific time. Such definitions, however, leave out the social dimensions of the meal. One solution is to analyse meals as part of the eating space, including dimensions such as the structure of eating, the sociability of eating and the formality of eating $(5,6)$. Another way of defining meals is by nutritionally distinguishing meals from eating events: "meals refers to either breakfast, lunch or dinner, and snacks refer to all other eating/drinking events" (3). Main meals contribute significantly more energy than do snacks, according to de Graaf, and with her argument in 
mind, it may be concluded that people who report continuous eating and drinking events throughout the day, without using these denominations, show the behaviour of grazing, i.e. an irregular eating pattern, compared with those who report structured and stable consumption of breakfast, lunch and dinner. Structured consumption of main meals with specific denominations was found in a generation of older women in Sweden (14). Although they showed a considerable number of eating occasions throughout the day, they all had a structured meal pattern with three main meals that they called breakfast, lunch/dinner and dinner/evening meal. These meals were also shown to be of nutritional significance, whereas the snacking, i.e. their eating occasions without specific names, was of little nutritional importance. These were women of the older generation who upheld traditions and cultural behaviours.

\section{Development of meal patterns}

What we all seem to experience is the meal in transformation (6). The fear of grazing and the disappearance of the family meal, with its cultural and nutritional consequences, are parts of an ongoing discussion and the focus of many meal researchers (15). For example, one definition of the word family is "those who eat together" (16). According to these discussions, if people stop eating together the existence of the family will be at risk (8, 15). Still, our knowledge of meal patterns, meal orders and the family meal in the past is scarce, leaving us with insufficient information on the development of these phenomena. Studies by historians, anthropologists, ethnologists and linguists indicate that meal patterns and meal orders in Sweden have changed considerably over the centuries $(10,17,18)$. There is some evidence for a two-meal-a-day pattern during the Viking era, with one meal early in the morning and one late at night. In-between meals were probably eaten, but no linguistic evidence exists for this. In the sixteenth century, additional denominations of meals are seen, and in the late nineteenth century, five to six denominations for different meals existed, implying that a stable meal structure had developed over the centuries. In one study, covering the period 1880 1980 in a small industrial society in northern Sweden, it was found that meal patterns had changed considerably during that period (19). From daily consumption of three hot meals and at least one sandwich meal around 1880, the industrial workers in 1980 only consumed two hot meals and at least two snacks consisting of mostly coffee and some sweet cakes. The reason for this change was explained by the change in working hours from a 12-14 hour working day to an 8 hour working day. However, a changed attitude among the workers, towards increased leisure time and fewer working hours at the factory, was also an important factor in this development. By voluntarily cutting down on time for consuming meals during working hours, the opportunities for eating hot meals were reduced. Snacks, easily eaten between meals, took the place of the hot cooked meal, eaten as a planned social interaction (20).

There is no doubt that in modern society there is a tendency towards increased grazing behaviour and perhaps also towards a decrease in sharing family meals $(8,15)$. This has been interpreted as revealing a society on its way towards increased individualism and non-conformism (15). As with many other commodities that are consumed, food, consumed as meals, can be a symbol of freedom. Grazing and skipping family meals may be seen as freedom from structure and prediction. These phenomena, however, require further investigation.

\section{Meal research as a new academic discipline}

Research on meals, or "meal research", has been developed and now represents two new academic disciplines in Sweden. The first department to establish this new academic discipline by establishing a professorship was the Department of Domestic Sciences, Uppsala University, soon followed by the Department of Catering Services, Örebro University $(21,22)$. The intention of this new research area is to take a holistic perspective on nutrition and food studies. Thus, the factors under examination include the consequences of food gatherings and food customs, how and why specific foods finally lie on a plate and are consumed in certain situations, food-related behaviours and rituals. Meal research includes studying people's food choice and meal habits, nutrient intake and the reasons why they have developed these habits $(21,22)$.

In the interdisciplinary MENEW project (Meals, Eating habits and Nutrient intake among Elderly Women), older women's food and meal habits were studied from a nutritional and sociocultural perspective $(14,23-25)$. It has been shown that for 
older women still living at home, independence in relation to food-related work, including shopping, cooking and serving food, is highly valued. This was true whether the woman was self-managing or disabled. Their striving for independence could be seen as something positive. However, disabled women were at risk of poor nutritional intake because they had lost their ability to cook for themselves. The women also valued the meal in everyday life and for many this daily activity symbolized a gift to their family. For widows, especially those who had recently lost their spouse, the whole meaning of cooking and eating was lost, and among these women poor nutritional intake may be a risk. Energy intake among older women in general may be at risk, especially among the oldest and most disabled women. Because underreporting was seen and because older women are reluctant to participate in food surveys, food in older women's everyday life seems to be a complex and sensitive area to study, and one that requires further attention.

Food and meals in special, elderly care housing is another area that has been examined (26). The fact that food symbolizes different meanings and that meals can be conceptualized in different ways by different individuals and groups was shown to have a negative effect on the final consequences of the meal in elderly care. Culinary rules, a combination of food items, specific menus and what foods are served in what dish, are based on traditions and customs, and are taken for granted in a given culture. Serving the wrong food or not serving the traditional trimmings with a specific dish can be experienced as destroying the whole meal. This was observed to happen on a daily basis in elderly care, thus diminishing the old people's wish to enjoy a meal in all respects. Politicians responsible for this special housing and the staff working there had different attitudes towards and knowledge about older people's conditions and wishes with regard to food and meals in their everyday lives. Those elderly who were most dependent on others, i.e. the sick and frail, were also the least able to choose food and meals, compared with those who were more independent (26). Overlooking the cultural and social aspects of the meal in elderly care may eventually lead to skipped meals, and may have nutritional consequences; however, this issue requires further research.
When examining preschool children's food habits and meal situation, it was shown that the energy and nutrient intakes of food at the preschool were lower than recommended, although this was compensated for by meals eaten at home (27). It was also shown that preschool children associated food and meals with rules and norms, and that at this age they had not yet begun to categorize food into good or bad food, but instead into food and non-food.

In a study carried out using focus group interviews with 17-year-olds, teenagers reported eating dinner with their family on a regular basis and that skipping the family meal was uncommon (28). However, the importance of experiencing social interaction at meals was more prevalent among the young women than the young men. The influence of different household members, especially children, on food purchasing and meals has been discussed in a recent study (29). It was shown, for example, that children influenced their parents to adapt to new consumer trends, including trying out new foods and sharing new knowledge about, for example, healthy foods. The social interaction between parents and children in the food store was shown to affect food purchase and education on food choices in everyday life. A public place such as a grocery store facilitates pedagogical situations and can work as a tool for informal education.

\section{Conclusion}

Foods combined into meals have different meanings for different individuals and groups. Through eating meals with different symbolic meaning, people also communicate their identity and social distinctions. Overlooking cultural and social aspects of the meal may have nutritional implications in the long run. Historical and linguistic data show that meal patterns in Sweden developed towards a structured and regular meal pattern during the late nineteenth century. The meal in transformation at the beginning of the twenty-first century is a tendency seen in Sweden and elsewhere in the Western world. However, the question of whether there is evidence showing the decline of the family requires more research. The aim of meal research as a new academic discipline at the Department of Domestic Sciences at Uppsala University is to contribute to this field by conducting further investigations that address the questions discussed above. 


\section{References}

1. Fjellström C, ed. Den glömda matfrågan. Om vetenskapsparadigm och forskningsinriktningar. I Näring för magen eller själen? Om svensk måltidsforskning 19802003. Dept of Domestic Sciences, Uppsala University and Academy of Meal Research; 2003. p. 8-25.

2. Smith D. The discourse of scientific knowledge of nutrition and dietary change in the twentieth century. In: Murcott A, ed. The nation's diet. London: Longman; 1998. p. 311-31.

3. de Graaf C. Nutritional definitions of the meal. In: Meiselman HL, ed. Dimensions of the meal. The science, culture, business, and art of eating. Gaithersburg, MD: Aspen; 2000. p. 47-59.

4. Prättälä R, Roos E. From regional ethnographies to interdisciplinary approaches - research on meals in Finland. Appetite 1999; 32: 66-72.

5. Mäkelä J. Cultural definitions of the meal. In: Meiselman HL, ed. Dimensions of the meal. The science, culture, business, and art of eating. Gaithersburg, MD: Aspen; 2000. p. 7-18.

6. Meiselman HL. Introduction. In: Meiselman HL, ed. Dimensions of the meal. The science, culture, business, and art of eating. Gaithersburg, MD: Aspen; 2000. p. 1.

7. Pliner P, Rozin P. The psychology of the meal. In: Meiselman HL, ed. Dimensions of the meal. The science, culture, business, and art of eating. Gaithersburg, MD: Aspen; 2000. p. 19-46.

8. Holm L. Family meals. In: Kjearnes U, ed. Eating patterns. A day in the lives of Nordic peoples. Report No. 7. Lysaker: SIFO; 2001. p. 199-212.

9. Kjærnes U, ed. Eating patterns. A day in the lives of Nordic peoples. Report No. 7. Lysaker: SIFO; 2001.

10. Bringéus NA. Man, food and milieu. A Swedish approach to food ethnology. East Linton: Tuckwell Press; 2001.

11. Sjögren-Beauchaine A. The bourgeoisie in the diningroom: meal ritual and cultural process in Parisian families of today. Stockholm: Stockholm University; 1988.

12. Sidenvall B, Fjellström C, Ek AC. Ritualized practices among caregivers at meals in geriatric care. Scand $\mathbf{J}$ Caring Sci 1996; 10: 53-61.

13. Borda B. Kost och etnisk identitet. In: Salomonsson A, ed. Mera än mat. Stockholm: Carlsson; 1987. p. 44-65.

14. Andersson J, Nydahl M, Gutsfasson K, Sidenval B, Fjellström C. Meals and snacks among elderly selfmanaging and disabled women. Appetite 2003; 41: 14960.

15. Warde A. Consumption, food and taste. Culinary antinomies and commodity culture. London: Sage; 1997.

16. Visser M. The rituals of dinner. The origins, evolution, eccentricities, and meaning of table manners. London: Penguin Books; 1993.
17. Ejder: Dagens tider och måltider. Skrifter utgivna genom Landsmålsarkivet i Lund nr 19. Lund: CWK Gleerup; 1969.

18. Morell M. Studier i den svenska livsmedelskonsumtionens historia. Hospitalshjonens livsmedelskonsumtion 1621-1872. Uppsala studies in economic history. Stockholm: Almqvist \& Wiksell International; 1989.

19. Fjellström C. Drömmen om det goda livet. Livskvalitet och matvanor i ett uppväxande industrisamhälle: Stocka sågverk 1870-1980. Thesis. Acta Ethnologica Umensia 1. Stockholm: Almqvist \& Wiksell International; 1990.

20. Douglas M, Nicod M. Taking the biscuit: the structure of British meals. New Society 1974; 30: 744-7.

21. Fjellström C. Nya professorer. Installationer våren 2002. Hushållsvetenskap, ssk måltidsforskning. Acta Univ Upsaliensis B 2002; 134: 55-7.

22. Gustafsson I-B. Måltidskunskap - ett nytt forskarutbildningsämne. Scand J Nutr 2002; 46: 104-6.

23. Sidenvall B, Nydahl M, Fjellström C. The meal as a gift - the meaning of cooking among retired women. J Appl Gerontol 2000; 4: 405-23.

24. Andersson J, Gustafsson K, Fjellström C, Sidenvall B, Nydahl M. Meals and energy intake among elderly women - an analysis of qualitative and quantitative dietary assessment methods. J Human Nutr Dietet 2001; 14: 467-76.

25. Fjellström C, Sidenvall B, Nydahl M. Food intake and the elderly - social aspects. In: Frewer LJ, Risvik E, Schifferstein H, eds. Food and people and society: a European perspective of consumers' food choice. Berlin: Springer; 2001. p. 197-209.

26. Mattsson Sydner Y, Fjellström C. The meaning of symbols of culinary rules. In: Edwards JSA, Gustafsson I-B, eds. Culinary arts and sciences IV. Global and national perspectives. Worshipful Company of Cooks Research Centre at Bournemouth University, England and Örebro University, Sweden; 2003. p. 363-71.

27. Wesslén A, Sepp H, Fjellström C. Swedish preschool children's experience of food. Int J Consumer Stud 2002; 26: 264-71.

28. Wesslén A. Teenager and food. The impact of culture and gender on attitudes towards food. Uppsala: Dept of Domestic Sciences, Uppsala University; 2000.

29. Pettersson A, Olsson U, Fjellström C. Family life in grocery stores - a study of interaction between adults and children. Int J Consumer Stud 2004; 28: 317-28.

\footnotetext{
Christina Fjellström

Department of Domestic Sciences

Uppsala University

Dag Hammarskjöldsväg 21

SE-752 37 Uppsala,

Sweden

Tel: +46 18 47| 2369

Fax: +46 |8 47| 2261

E-mail: Christina.fjellstrom@ihv.uu.se
} 